\title{
DETERMINAN MOTIVASI KERJA PEGAWAI DAN KINERJA PANTI ASUHAN DI YOGYAKARTA
}

\author{
Suryo Pratolo \\ Program Studi Akuntansi Fakultas Ekonomi dan Bisnis Universitas Muhammadiyah Yogyakarta \\ suryo@umy.ac.id \\ Javanti Binary \\ Program Studi Akuntansi Fakultas Ekonomi dan Bisnis Universitas Muhammadiyah Yogyakarta \\ javanti@umy.ac.id \\ Hafiez Sofyani \\ Program Studi Akuntansi Fakultas Ekonomi dan Bisnis Universitas Muhammadiyah Yogyakarta \\ hafiez.sofyani@umy.ac.id
}

\begin{abstract}
Abstrak: Determinan Motivasi Kerja Pegawai dan Kinerja Panti Asuhan di Yogyakarta. Penelitian ini bertujuan untuk menguji pengaruh akuntabilitas, budaya organisasi dan kepemimpinan etis terhadap motivasi kerja pegawai dan terhadap kinerja panti asuhan. Penelitian ini menggunakan pendekatan uji korelasi yang berguna untuk menjelaskan ada tidaknya hubungan antar variabel. Dalam penelitian ini sampel terdiri dari 30 panti asuhan dipilih menggunakan teknik random sampling. Uji korelasi dengan teknik analisis regresi berganda digunakan untuk menguji hipotesis. Sebelum kami menguji hipotesis, analisis faktor dan uji asumsi klasik dilakukan untuk menguji validitas dan reliabilitas instrumen dan kualitas data. Hasil penelitian menunjukkan bahwa budaya organisasi dan kepemimpinan etis berpengaruh positif terhadap motivasi kerja karyawan panti asuhan dan kinerja panti asuhan. Sedangkan akuntabilitas hanya secara positif memengaruhi kinerja panti asuhan dan tidak terhadap motivasi kerja karyawan panti asuhan.
\end{abstract}

Kata kunci: akuntabilitas, kepemimpinan etis, komitmen organisasi, budaya organisasi, kinerja organisasi, kepemimpinan transformasional, motivasi kerja

\begin{abstract}
Determinants of Employee Work Motivation and Orphanage Performance in Yogyakarta. This study aims to examine the influence of accountability, organizational culture and ethical leadership on work motivation of employee and performance of orphanage. This study uses a correlation test approach that is useful to explain the relationships between variables. In this study the sample consisted of 30 orphanages selected using a random sampling technique. Correlation test with multiple regression analysis techniques is used to test hypotheses. However, before we tested the hypotheses, a factor analysis and classical assumption test are carried out to test the validity and reliability of the instrument and the quality of the data. The result revealed that organizational culture and ethical leadership have a positive influence on the work motivation of orphanage employees and the orphanage's performance. While accountability only influence positively toward the orphanage's performance and not toward work motivation of orphanage employees.
\end{abstract}

Keywords: accountability, ethical leadership, organizational commitment, organizational culture, organizational performance, transformational leadership, work motivation

\section{PENDAHULUAN}

Berdasarakan UU No. 32 Tahun 2004

tentang Pemerintah Daerah, panti asuhan merupakan lembaga sosial yang membantu pemerintah daerah dalam melaksanakan usaha kesejahteraan sosial yang berada di 


\section{Nominal: Barometer Riset Akuntansi dan Manajemen}

P-ISSN: 2303-2065 E-ISSN: 2502-5430

Volume 9 No 1 (2020)

wilayah kota atau kabupaten. Mengacu pada data dari Badan Pusat Statistik Daerah Istimewa Yogyakarta dalam angka 2016 menunjukkan bahwa Dinas Sosial Provinsi D.I. Yogyakarta mencatat jumlah fasilitas sosial panti asuhan tahun 2015 sebanyak 70 unit dengan jumlah anak asuh sebanyak 3.101. Sedangkan, dari website Panti Basa, data terakhir tahun 2016 menunjukkan bahwa panti asuhan di Daerah Istimewa Yogyakarta terdapat sekitar 118 unit panti asuhan dengan rincian 44 unit panti asuhan berada di kabupaten Sleman, 15 unit di kota Yogyakarta, 20 unit di kabupaten Bantul, 27 unit di Kulon Progo, dan 12 unit di kabupaten Gunung Kidul (Panti-Basa, 2016).

Meningkatnya pembangunan panti asuhan diiringi dengan regulasi yang dikeluarkan oleh pemerintah melalui Keputusan Menteri Sosial RI No. 50/HUK/2004 tentang Standardisasi Panti Sosial dan Pedoman Akreditasi Panti Asuhan. Standar tersebut disahkan agar peningkatan profesionalisme pelayanan kesejahteraan sosial khususnya di panti asuhan dapat berjalan baik. Selain itu, dengan regulasi tersebut, diharapkan panti asuhan dapat menjalankan tugas mereka sebagaiman mestinya. Namun, dalam praktiknya masih banyak kasus tindak kekerasan di panti asuhan dari tahun ke tahun. Hal ini diantaranya disebabkan daya dukung kelembagaan yang lemah dan kurangnya sumber daya manusia (SDM), finansial, dan fasilitas yang dimiliki (Johan, 2006).

Meskipun pemerintah telah memperketat regulasi penyelenggaraan panti asuhan dengan tujuan agar organisasi sosial ini menjalankan visi dan misi dan programprogramnya sesuai prosedur, namun demikian, pada 2019 ditemukan adanya berita panti asuhan tidak menjalankan tugasnya dengan baik. Dampaknya adalah banyak anak panti yang berada dalam kondisi prihatin dan kurang terurus. Kondisi ini akhirnya memicu komplain dari berbegai pihak (jurnalsumatra.com, 2019).

Di sisi lain, hingga saat ini penelitian terkait kinerja panti asuhan masih sangat minim dilakukan, khususnya terkait faktorfaktor yang mendorong agar panti asuhan berkinerja dan pegawainya memiliki motivasi kerja yang tinggi. Untuk menutupi celah ini, diperlukan kajian terkait faktor penentu kinerja panti asuhan baik dari sistem organisasi, personal dan kepemimpinan. Merujuk pada beberapa referensi, hal utama yang memengaruhi kinerja suatu organisasi adalah faktor personal, kepemimpinan, dan sistem yang berlaku di organisasi (Rumintjap, 2013) Apabila faktor tersebut dapat dijalankan dengan baik, maka kinerja yang dicapai akan maksimal (Imelda 2005).

Pada studi ini, faktor personal terkait dengan motivasi pegawai di dalamnya, faktor kepemimpinan merujuk pada etika kempe- 


\section{Nominal: Barometer Riset Akuntansi dan Manajemen}

P-ISSN: 2303-2065 E-ISSN: 2502-5430

Volume 9 No 1 (2020)

mimpinan yang dijalankan, sementara sistem organisasi yang dimaksud di sini merujuk pada tata kelola yakni akuntabilitas dan budaya organisasi. Secara eksplisit, studi ini bertujuan untuk menguji pengaruh akuntabilitas, budaya organisasi dan kepemimpinan etis terhadap motivasi kerja pegawai panti asuhan dan terhadap kinerja panti asuhan.

\section{KAJIAN LITERATUR}

Dalam penelitian yang dilakukan Seliamang (2015) ditemukan bahwa akuntabilitas yang dijalankan dapat meningkatkan motivasi kerja pegawai dan berikutnya meningkatkan kinerja organisasi panti asuhan. Menurut Hara (2016) akuntabilitas yang baik mengindikasikan rasa tanggungjawab yang kuat dalam mengelola organisai. Akuntabilitas juga menjadi sumber informasi bagi organisasi sehingga pengambilan keputusan dalam rangka memberikan pelayanan terbaik dapat dilakukan (Sofyani dan Akbar, 2013).

Akuntabilitas merupakan bentuk pertanggungjelasan pengelola kepada pemangku kepentingan dengan menyajikan, melaporkan, dan mengungkapkan segala aktivitas serta kegiatan dalam orgnisasi (Mahsun et al., 2013; Ulum dan Sofyani, 2016). Informasi panti asuhan secara spesifik disampaikan kepada masyarakat, pemerintah dan donatur. Adanya akuntabilitas mengindikasikan komitmen lembaga dalam menerapkan praktik tata kelola yang baik di dalam organsasi. Hal ini dapat menjadi legitimasi dan sinyal positif kepada pemangku kepentingan, termasuk para pengelola yang terlibat dalam penyelenggaraan panti asuhan (Spence, 2002; Celani dan Singh, 2011; Connelly et al., 2011). Adanya akuntabilitas yang baik dapat meningkatkan kepercayaan dan semangat kerja para anggota organisasi karena mereka menjadi lebih yakin bahwa organisasi memilliki kejujuran dan keterbukaan tinggi. Hal ini selanjutnya akan mendorong anggota untuk berusaha dengan baik dalam menjalankan tugas dan wewenangnya (Certo, 2003). Dengan demikian, semakin tinggi akuntabilitas, semakin tinggi pula motivasi kerja dan kinerja.

H1a: Akuntabilitas berpengaruh positif terhadap motivasi kerja.

H1b: Akuntabilitas berpengaruh positif terhadap kinerja panti asuhan.

Selanjutnya, aspek lain yang berkaitan dengan kinerja organisasi adalah budaya di dalam organisasi itu sendiri. Budaya yang baik dan tumbuh dari nilai-nilai positif yang ada di dalam organiasasi dapat memengaruhi perilaku anggota dalam beraktivitas karena menciptakan lingkungan kerja yang baik dalam mencapai tujuan organisasi (Kurniawan, 2013). Budaya organisasi merupakan suatu sistem pengertian atau pemahaman yang sama diantara para anggota mengenai nilai-nilai, kebijaksanaan, asumsi 


\section{Nominal: Barometer Riset Akuntansi dan Manajemen}

P-ISSN: 2303-2065 E-ISSN: 2502-5430

Volume 9 No 1 (2020)

dan kepercayaan yang berkaitan dengan organisasi sebenarnya dan perilaku yang seharusnya dilakukan oleh anggota (Robbins dan Judge, 2008). Dengan budaya organisasi yang dapat menciptakan lingkungan kerja yang kondusif, para penggerak organisasi akan terdorong untuk bersemangat dalam bekerja. Dalam penelitian yang dilakukan oleh Shalahuddin dan Marpaung (2016) serta Susanto dan Aisiyah (2010) ditemukan bahwa budaya organisasi berpengaruh positif dan signifikan terhadap motivasi kerja.

Menurut Robbin (1995) budaya organisasi dengan nilai-nilai kekeluargaan dan kebersamaan, keseimbangan dan kesejajaran, kejujuran dan keterbukaan serta saling percaya dan saling menghargai menjadi dasar dalam menjalankan organisasi dapat meningkatkan kinerja. Dengan norma suatu organisasi dapat beradaptasi dengan lingkungan, segala aktivitas dijalankan dengan senang hati sehingga dapat mencapai tujuan organisasi. Dalam penelitian yang dilakukan oleh Kurniawan (2013), Arifin (2014), dan Hara (2016), serta menunjukkan bahwa budaya organisasi berpengaruh positif terhadap kinerja organisasi.

H2a: Budaya organisasi berpengaruh positif terhadap motivasi kerja.

$\mathrm{H} 2 \mathrm{~b}$ : Budaya organisasi berpengaruh positif terhadap kinerja panti asuhan.

Selanjutnya, kesuksesan organisasi dalam mencapai tujuan organisasi juga dipe- ngaruhi oleh bagaimana pemimpin menjalankan organisasi, mengelola sumber daya, dan mengatur anggota untuk menjalankan tugas. Salah satu isu berkenaan dengan kepemimpinan ini adalah etchical leadership. Dalam penelitian yang dilakukan oleh Seliamang (2015) ditemukan bahwa semakin tinggi ethical leadership maka semakin tinggi kinerja panti asuhan. Etchical leadership memberikan teladan dan kesadaran pada anggota pentingnya tujuan organisasi. Hal ini dapat memberikan pengaruh positif agar anggota menjalankan aktivitas organisasi sesuai dengan target dan sasaran organisasi, sehingga tujuan organisasi dicapai dengan maksimal.

Menurut Wibowo (2016) ethical leadership merupakan sikap seseorang yang adil, jujur dan terpercaya, dimana dimensi moral menjadi ciri-ciri kepribadian pemimpin. Pemimpin yang etis dicirikan dengan mereka yang melibatkan anggota untuk berpartisipasi aktif dalam setiap keputusan yang diambil mempertimbangkan kesejahteraan anggota. Sikap pemimpin yang etis membuat anggota merasa dihargai, dilindungi dan diakui keberadaanya. Hal ini dapat mendorong semangat kerja anggota. Dalam penelitian yang dilakukan oleh Baihaqi (2013) kepemimpinan mempunyai pengaruh positif dan signifikan terhadap motivasi kerja. 


\section{Nominal: Barometer Riset Akuntansi dan Manajemen}

P-ISSN: 2303-2065 E-ISSN: 2502-5430

Volume 9 No 1 (2020)

Menurut Nugroho (2013) kepemimpinan yang baik haruslah dijalankan dengan sadar dan berdasarkan prinsip-prinsip etis yang sesuai dengan nilai-nilai yang dianut organisasi. Adanya perilaku etis akan menciptakan suasana kerja yang lebih nyaman, pemimpin mementingkan kesuksesan organisasi, setiap keputusan yang diambil mempertimbangkan nilai-nilai etis sehingga output yang diperoleh maksimal. Dalam penelitian yang dilakukan Seliamang (2015) menunjukkan bahwa ethical leadership berpengaruh positif dan signifikan terhadap kinerja organisasi panti asuhan.

H3a: Ethical Leadership berpengaruh positif terhadap motivasi kerja.

H3b: Ethical Leadership berpengaruh positif terhadap kinerja panti asuhan.

Motivasi diartikan sebagai suatu kondisi mental yang memengaruhi perilaku seseorang karena memberikan tujuan, intensitas dan kegigihan untuk melakukan suatu hal sesuai tujuan tertentu (Hughes, 2012). Motivasi kerja penting dimiliki oleh seluruh pegawai sebagai dorongan untuk memenuhi kebutuhan sehingga pegawai dapat menyesuaikan dengan lingkungannya secara positif agar juga dapat mencapai tujuan yang hendak dicapai dan menyelesaikan tugas organisasi dengan efektif. Dengan demikian, tujuan, sasaran dan harapan organisasi dapat dicapai. Dalam penelitian yang dilakukan oleh Hara (2016) serta Ridwan (2019) menunjukkan bahwa motivasi mempunyai pengaruh positif dan signifikan terhadap kinerja organisasi.

H4: Motivasi kerja berpengaruh positif terhadap kinerja panti asuhan.

Berangkat dari pengembangan hipotesis di atas, maka model penelitian yang dirumuskan adalah sebagaimana disajikan pada Gambar 1.

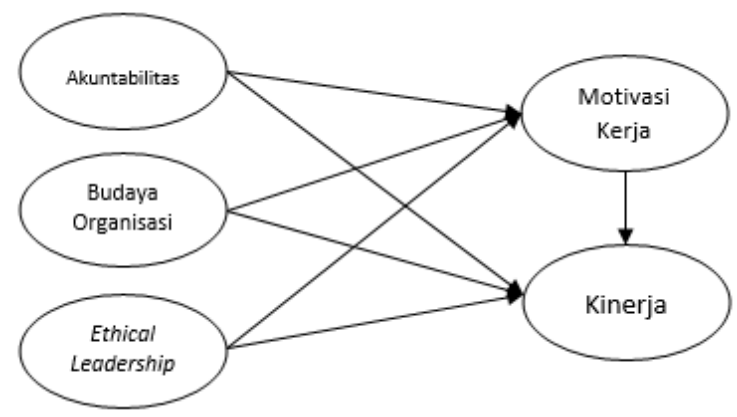

Gambar 1: Model Penelitian

\section{METODE PENELITIAN}

Populasi dalam penelitian ini adalah 118 Panti Asuhan yang ada di Daerah Istimewa Yogyakarta, dengan pengambilan sampel sebanyak 30 panti asuhan. Teknik pengambilan sampel yang digunakan dalam penelitian ini dikategorikan kedalam kelompok probability sampling yaitu teknik pengambilan sampel dengan memberikan peluang yang sama pada setiap unsur populasi yang dipilih menjadi sampel dalam penelitian (Sugiyono, 2008). Untuk mempersempit cakupan area penyebaran kuesioner, dalam penelitian ini hanya diambil sampel 30 panti asuhan secara acak. Teknik pengambilan sampel dari populasi ini secara 


\section{Nominal: Barometer Riset Akuntansi dan Manajemen}

P-ISSN: 2303-2065 E-ISSN: 2502-5430

Volume 9 No 1 (2020)

acak tanpa memperhatikan strata yang ada dalam populasi dapat disebut dengan simple random sampling. Hal ini dikare-nakan tidak ada kriteria tertentu yang harus dipenuhi untuk dapat dipilih menjadi sampel. Oleh sebab itu semua panti asuhan yang ada di Jogja memiliki kesempatan yang sama untuk dipilih menjadi sampel.

Menurut sifatnya, jenis data dalam penelitian ini adalah data kuantitatif. Menurut sumber pengambilannya, penelitian ini menggunakan data primer. Sumber data primer dalam penelitian ini meliputi pemimpin dan pengelola panti asuhan, meliputi pengurus, pendamping dan pengasuh tiap unit panti asuhan. Penelitian ini dilakukan dengan menyebarkan kuesioner kepada setiap unit panti asuhan yang kemudian dikumpulkan secara langsung. Teknik pengumpulan data dalam penelitian ini menggunakan metode survey yaitu metode pengumpulan data primer dengan menggunakan instrumen kuesioner yang disebarkan kepada responden (Hartono, 2013). Peneliti memberikan instrumen kuesioner (angket) kepada responden dalam bentuk pertanyaanpertanyaan yang berkaitan dengan penelitian yang diteliti (Sugiyono, 2008). Pernyataanpernyataan tersebut disusun secara terstruktur agar dapat menghasilkan informasi mengenai akuntabilitas, budaya organisasi, ethical leadership, motivasi kerja pegawai, dan kinerja panti asuhan sesuai dengan penelitian yang akan dilakukan. Survei kuesioner penelitian ini dikelompokkan dalam ke dalam pick up survey. Jadi, peneliti menyebarkan kuesioner kepada masingmasing responden dan hasil pengisian kuesioner akan diambil secara pribadi oleh peneliti.

Tabel 1. Operasionalisasi Variabel

\begin{tabular}{|c|c|c|}
\hline Variabel & Dimensi & Indikator \\
\hline $\begin{array}{l}\text { Akuntabil } \\
\text { itas }\end{array}$ & $\begin{array}{l}\text { Akuntabilitas } \\
\text { Keuangan }\end{array}$ & $\begin{array}{l}\text { Penyampaian } \\
\text { laporan } \\
\text { keuangan } \\
\text { dengan benar. } \\
\text { Informasi } \\
\text { lengkap sesuai } \\
\text { dengan harapan. } \\
\text { Informasi } \\
\text { mempermudah } \\
\text { organisasi dalam } \\
\text { penilaian kinerja } \\
\text { di masa lalu. } \\
\text { Informasi } \\
\text { mempertajam } \\
\text { organisasi dalam } \\
\text { membuat } \\
\text { perencanaan } \\
\text { kinerja di masa } \\
\text { yang akan } \\
\text { dating. }\end{array}$ \\
\hline $\begin{array}{l}\text { Budaya } \\
\text { Organisas } \\
\text { i }\end{array}$ & $\begin{array}{l}\text { Orientasi } \\
\text { terhadap tim }\end{array}$ & $\begin{array}{l}\text { Kerjasama } \\
\text { dalam } \\
\text { penyelesaian } \\
\text { tugas. } \\
\text { Koordinasi kerja } \\
\text { antar anggota } \\
\text { dan pimpinan. } \\
\text { Meningkatkan } \\
\text { tingkat } \\
\text { kreativitas. } \\
\text { Pentingnya } \\
\text { tanggungjawab } \\
\text { diri pada } \\
\text { organisasi. }\end{array}$ \\
\hline $\begin{array}{l}\text { Ethical } \\
\text { Leadershi } \\
p\end{array}$ & Religiusitas & $\begin{array}{l}\text { Adanya aturan } \\
\text { ibadah sesuai } \\
\text { afiliasi agama } \\
\text { dari panti } \\
\text { asuhan. }\end{array}$ \\
\hline
\end{tabular}




\begin{tabular}{|c|c|c|}
\hline Variabel & Dimensi & Indikator \\
\hline & Integritas & $\begin{array}{l}\text { Menerapkan } \\
\text { ilmu agama } \\
\text { dalam } \\
\text { organisasi. } \\
\text { Ketaatan pada } \\
\text { peraturan kode } \\
\text { etik. } \\
\text { Memberikan } \\
\text { informasi } \\
\text { dengan jujur dan } \\
\text { terus terang. }\end{array}$ \\
\hline $\begin{array}{l}\text { Motivasi } \\
\text { Kerja } \\
\text { Pengurus }\end{array}$ & Keterhubungan & $\begin{array}{l}\text { Rasa } \\
\text { tanggungjawab. } \\
\text { Semangat kerja. } \\
\text { Partisipasi aktif. } \\
\text { Dorongan } \\
\text { mencapai } \\
\text { tujuan. }\end{array}$ \\
\hline $\begin{array}{l}\text { Kinerja } \\
\text { panti } \\
\text { asuhan }\end{array}$ & $\begin{array}{l}\text { Perspektif } \\
\text { Kepuasan } \\
\text { Pelanggan } \\
\text { Perspektif } \\
\text { Keuangan } \\
\text { Perspektif } \\
\text { Bisnis Internal }\end{array}$ & $\begin{array}{l}\text { Wujud fisik, } \\
\text { keandalan, daya } \\
\text { tanggap, } \\
\text { jaminan, empati. } \\
\text { Ekonomis, } \\
\text { efektif, efisien. } \\
\text { Sarana dan } \\
\text { prasaranan. } \\
\text { Keberadaan } \\
\text { Standar } \\
\text { operasional } \\
\text { prosedur. } \\
\text { Peningkatan } \\
\text { jumlah anak } \\
\text { asuh, inovasi } \\
\text { suasana dalam } \\
\text { bekerja. }\end{array}$ \\
\hline
\end{tabular}

Penelitian ini menggunakan empat variabel independen yaitu akuntabilitas, budaya organisasi, ethical leadership, dan motivasi kerja. Adaapun variabel dependen adalah kinerja panti asuhan. Motivasi kerja pegawai juga berlaku sebagai variabel independen atas kinerja panti asuhan. Semua variabel dalam penelitian diukur dengan skala pengukuran yaitu skala likert (1) sampai dengan (5) yang menyatakan bahwa responden tidak setuju atau setuju terhadap pernyataan kuesioner yang dapat dilihat pada tabel pengukuran. Operasionalisasi variabel secara detil disajikan pada Tabel 1 .

\section{HASIL PENELITIAN DAN PEMBAHASAN}

Tabel 2 menyajikan jumlah panti asuha yang menjadi sampel penelitian, tabel 3 menyajikan tingkat respon dari para responden atas penyebaran kuesioner, dan tabel 4 menyajikan statistik deskriptif dari semua variabel yang terlibat dalam penelitian ini.

Tabel 2. Jumlah Panti Asuhan yang Menjadi Sampel Menurut Kabupaten dan Kota di D.I. Yogyakarta

\begin{tabular}{|c|c|c|c|}
\hline No. & Keterangan & Jumlah & $(\%)$ \\
\hline 1 & Kota & 2 & 6,67 \\
\hline & Yogyakarta & & \\
\hline 2 & $\begin{array}{l}\text { Kabupaten } \\
\text { Sleman }\end{array}$ & 8 & 26,67 \\
\hline 3 & $\begin{array}{l}\text { Kabupaten } \\
\text { Bantul }\end{array}$ & 6 & 20,00 \\
\hline 4 & $\begin{array}{l}\text { Kabupaten } \\
\text { Gunung } \\
\text { Kidul }\end{array}$ & 6 & 20,00 \\
\hline 5 & $\begin{array}{l}\text { Kabupaten } \\
\text { Kulon Progo }\end{array}$ & 8 & 26,67 \\
\hline Total & & 30 & 100,00 \\
\hline
\end{tabular}

Sebelum dilakukan uji hipotesis, terlebih dahulu dilakukan uji validitas dan reliabilitas instrumen. Uji validitas diguna-kan untuk menguji valid atau tidaknya kuesioner penelitian, kuesioner atau instrumen dikatakan valid apabila hasil uji Uji Korelasi Pearson Product Moment menunjukkan bahwa nilai $r$ hitung $>r$ tabel $(0,361)$.

Tabel 3. Tingkat Respon Atas Kuesioner 


\begin{tabular}{lc}
\hline Keterangan & Jumlah \\
\hline Kuesioner yang disebar & 120 \\
Kuesioner yang kembali & 115 \\
Kuesioner yang tidak dapat diolah & 0 \\
\hline Usable Respons Rate (\%) & $\mathbf{9 5 , 8 3}$ \\
\hline
\end{tabular}

Hasil uji yang kami lakukan menmukan bahwa Nilai $r$ hitung seluruh hasil uji validitas lebih besar dari $r$ tabel $(0,361)$ dan nilai Sig. 0,000 < alpha 0,05. Hal ini berarti seluruh item dalam kuesioner tersebut valid dalam mengukur variabel penelitian (Ghozali, 2012; Nazaruddin \& Basuki, 2015).

Tabel 4. Statistik Deskriptif $(\mathrm{N}=30)$

\begin{tabular}{|c|c|c|c|c|}
\hline Variabel & Min. & Max. & Mean & $\begin{array}{l}\text { Std. } \\
\text { Dev. }\end{array}$ \\
\hline Akuntabilitas & 14.33 & 20.00 & 17.2000 & 1.33749 \\
\hline $\begin{array}{l}\text { Budaya } \\
\text { Organisasi }\end{array}$ & 15.50 & 20.00 & 17.0667 & 1.19794 \\
\hline $\begin{array}{l}\text { Ethical } \\
\text { Leadership }\end{array}$ & 14.00 & 20.00 & 17.3277 & 1.55139 \\
\hline $\begin{array}{l}\text { Motivasi } \\
\text { Kerja }\end{array}$ & 14.50 & 20.00 & 16.8053 & 1.44450 \\
\hline $\begin{array}{l}\text { Kinerja Panti } \\
\text { Asuhan }\end{array}$ & 47.33 & 64.75 & 53.1610 & 3.95391 \\
\hline
\end{tabular}

Selanjutnya dilaukan uji reliabilitas untuk mengetahui reliabilitas kuesioner yang digunakan dalam mengukur variable variabel penelitian. Uji ini menggunakan uji Cronbach Alpha dengan bantuan Software SPSS, dengan ketentuan jika nilai koefisien alpha > 0,70 maka dapat disimpulkan bahwa instrumen yang digunakan handal atau reliabel. Dari hasil uji reliabilitas menunjukkan bahwa semua variabel dalam penelitian memiliki nilai Cronbach's Alpha lebih besar dari 0,70 dan bahkan semuanya lebih besar dari 0,80. Dengan demikian reliabilitas instrumen dakatakan tinggi (Ghozali, 2012; Nazaruddin \& Basuki, 2015).

Selanjutnya, dilakukan uji asumsi klasik yang terdiri dari uji normalitas, multikolinearitas dan heteroskedastisitas. Hasil uji normalitas menggunakan uji Kolmogorov Smirnov menemukan bahwa nilai sig. sebesar 0,632 > alpha $(0,05)$ yang berarti data berdistribusi normal. Berikutnya uji heteroskedastisitas dengan uji Glesjer menunjukkan bahwa nilai signifikansi lebih besar dari alpha 0,05 untuk seluruh variabel, maka model regresi tidak terkena heteroskedastisitas atau varians residual tersebut homogen. Selanjutnya, hasil uji multikolinearitas melalui nilai tolerance pada semua variabel independen adalah lebih dari 0,1 dan untuk nilai VIF kurang dari 10 . Dengan demikian dapat disimpulkan bahwa tidak terjadi multikolinearitas di antara masing-masing variabel independen (Ghozali, 2012; Nazaruddin \& Basuki, 2015). Mengacu pada semua hasil uji validitas dan reliabilitas instrument serta uji asumsi klasik yang terpenuhi, maka pengujian hipotesis dapat dilakukan.

Tabel 5 menyajikan hasil uji hipotesis dari penelitian ini. Berdasarkan Tabel 5 dapat dilihat nilai variabel akuntabilitas menunjukkan bahwa t hitung sebesar -0,850 <2,064 ( $t$ tabel) dan nilai Sig. sebesar 0,404 > alpha 


\section{Nominal: Barometer Riset Akuntansi dan Manajemen}

P-ISSN: 2303-2065 E-ISSN: 2502-5430

Volume 9 No 1 (2020)

0,05, maka H1a ditolak, artinya akuntabilitas tidak berpengaruh terhadap motivasi kerja.

Dapat disimak pula pada Tabel 1 bahwa nilai variabel Akuntabilitas menunjukkan bahwa $t$ hitung sebesar 2,136 > 2,069 (t tabel) dan nilai Sig. sebesar 0,044 < alpha 0,05, maka H1b diterima, artinya akuntabilitas berpe-ngaruh positif signifikan terhadap kinerja panti asuhan. Sementara nilai variabel budaya organisasi menunjukkan bahwa $t$ hitung sebesar 4,091 > 2,064 ( $\mathrm{t}$ tabel) dan nilai Sig. sebesar 0,000 < alpha 0,05 H2a diterima, artinya budaya organisasi berpengaruh positif dan signifikan terhadap motivasi kerja. Selanjutnya, nilai variabel Budaya Organisasi menunjukkan bahwa $t$ hitung sebesar 3,853 > 2,069 ( $t$ tabel) dan nilai Sig. sebesar 0,001 < alpha 0,05, maka $\mathrm{H} 2 \mathrm{~b}$ diterima, artinya budaya organisasi berpengaruh positif signifikan terhadap kinerja panti asuhan.

Tabel 5. Hasil Uji Hipotesis

\begin{tabular}{|c|c|c|c|c|}
\hline Variabel & Kode & Arah & Koef & Sig. \\
\hline Akuntabilitas & $\mathrm{H}_{1 \mathrm{a}}$ & + & $\begin{array}{c}- \\
0,152\end{array}$ & 0,404 \\
\hline Akuntabilitas & $\mathrm{H}_{1 \mathrm{~b}}$ & + & 0,161 & $\begin{array}{c}0,044 \\
*\end{array}$ \\
\hline $\begin{array}{l}\text { Budaya } \\
\text { Organisasi }\end{array}$ & $\mathrm{H}_{2 \mathrm{a}}$ & + & 0,491 & $\begin{array}{c}0,000 \\
*\end{array}$ \\
\hline $\begin{array}{l}\text { Budaya } \\
\text { Organisasi }\end{array}$ & $\mathrm{H}_{2 \mathrm{~b}}$ & + & 0,250 & $\begin{array}{c}0,001 \\
*\end{array}$ \\
\hline $\begin{array}{l}\text { Ethical } \\
\text { Leadership }\end{array}$ & $\mathrm{H}_{3 \mathrm{a}}$ & + & 0,618 & $\begin{array}{c}0,001 \\
*\end{array}$ \\
\hline $\begin{array}{l}\text { Ethical } \\
\text { Leadership }\end{array}$ & $\mathrm{H}_{3 b}$ & + & 0,228 & $\begin{array}{c}0,017 \\
*\end{array}$ \\
\hline $\begin{array}{l}\text { Motivasi } \\
\text { Kerja } \\
\text { Pengurus }\end{array}$ & $\mathrm{H}_{4}$ & + & 0,201 & $\begin{array}{c}0,027 \\
*\end{array}$ \\
\hline
\end{tabular}

Beriktunya, nilai variabel ethical leadership menunjukkan bahwa $t$ hitung sebesar 3,593 > 2,064 ( $t$ tabel) dan nilai Sig. sebesar 0,001 < alpha 0,05, maka H3a diterima, artinya ethical leadership berpengaruh positif dan signifikan terhadap motivasi kerja. Nilai variabel Ethical Leadership menunjukkan bahwa $t$ hitung sebesar 2,577 > 2,069 ( $t$ tabel) dan nilai Sig. sebesar 0,017 < alpha 0,05, maka H3b diterima, artinya ethical leadership juga berpengaruh positif signifikan terhadap kinerja panti asuhan. Terakhir, berdasarkan informasi di Tabel 2, nilai $t$ hitung sebesar 2,371 > 2,069 ( $t$ tabel) dan nilai Sig. sebesar 0,027 < alpha 0,05, maka H4 diterima, artinya motivasi kerja berpengaruh positif signifikan terhadap kinerja panti asuhan.

\section{Pembahasan}

Akuntabilitas merupakan bentuk pertanggungjelasan keuangan dan kegiatan panti asuhan kepada para pemangku kepentingan yakni masyarakat, pemerintah, donatur termasuk pegawai di panti asuhan itu sendiri. Akuntabilitas yang baik dapat meningkatkan kepercayaan dan membangun sebuah hubungan yang baik antara organisasi dan para pemangku kepentingan (Nurrizkiana, Handayani, \& Widiastuty, 2017). Namun, pada penelitian ini ditemukan bahwa akuntabilitas hanya berpengaruh terhadap kinerja organisasi dan tidak berpengaruh 


\section{Nominal: Barometer Riset Akuntansi dan Manajemen}

P-ISSN: 2303-2065 E-ISSN: 2502-5430

Volume 9 No 1 (2020)

kepada motivasi kerja pegawai. Hal ini menunjukkan bahwa akuntabilitas mempermudah organisasi dalam memperbaiki kinerja dan mempertajam kinerja dimasa depan, namun belum memicu motivasi kerja para pegawai. Hal ini bisa jadi disebabkan pegawai panti tidak mengamati atau berkepentingan kepada akuntabilitas panti asuhan. Hasil ini sejalan dengan Seliamang (2015), Hara (2016), serta Arifin (2014) yang juga menyimpulkan bahwa akuntabilitas mempunyai pengaruh positif terhadap kinerja organisasi.

Pada kondisi akuntabilitas yang baik, organisasi benar-benar mempertanggungjelaskan segala aktivitas sesuai dengan sasaran dan program kerja yang telah dibuat. Akuntabilitas juga menggiring organisasi memiliki program kerja yang lebih jelas dan penggunaan dana dengan tepat, sehingga kinerja organisasi yang dihasilkan meningkat (Auditya \& Husaini, 2013; Putra, 2013).

Namun, akuntabilitas yang tidak berdampak pada motivasi kerja pegawai bisa jadi dikarenakan fenomena di lapangan yang memang ditemui bahwa fokus akuntabilitas, baik penyusunan dan penggunaan laporan akuntabilitas, baik inforamasi kinerja dari laporan keuangan maupun kegiatan panti asuan, masih berada pada manajemen level puncak, atau pengurus harian. Hal ini menjadikan akuntabilitas memang hanya digunakan para pengurus harian untuk fokus pada pembenahan kinerja panti tanpa membidik upaya peningkatan motivasi kerja pegawai. Di lapangan juga ditemui bahwa pegawai panti asuhan bekerja dengan instruksi dari atasan atau pengurus harian. Tanpa melihat akuntabilitas panti, para pegawai senantiasa melaksanakan pekerjaan yang ditugaskan kepada mereka secara patuh.

Hasil penelitian ini sesuai dengan hasil penelitian yang dilakukan oleh Kurniawan (2013), Hara (2016), dan Arifin (2014) yang juga menemukan bahwa budaya organisasi berpengaruh positif dan signifikan terhadap kinerja organisasi publik. Penelitian ini menguatkan bahwa budaya organisasi menjadi aspek penting dalam memicu motivasi kerja pegawai dan kinerja organisasi. Budaya organisasi yang baik dan kondusif akan mendorong anggota dalam organsasi untuk melaksanakan tujuan organisasi secara ideal (Lina, 2014; Trang, 2013). Lingkungan sosial yang terjalin dengan baik dan dibangun dari budaya di dalam organisasi ini mendorong semangat kerja anggota (Indayati, 2012). Robbins (1995) menjelaskan bahwa dengan nilai-nilai kekeluargaan, kebersamaan, kejujuran, keterbukaan, saling percaya dan saling menghargai dalam menjalankan organisasi dapat meningkatkan motivasi kerja dan berkinerja. Kondisi ini selanjutnya berdampak secara positif pada kinerja 


\section{Nominal: Barometer Riset Akuntansi dan Manajemen}

P-ISSN: 2303-2065 E-ISSN: 2502-5430

Volume 9 No 1 (2020)

organisasi panti asuhan itu sendiri (Murti \& Srimulyani, 2013).

Aspek penting lain dari upaya meningkatkan motivasi kerja pegawai dan kinerja panti asuhan adalah adanya ethical leadership. Organisasi panti asuhan adalah organisasi yang bergerak dibidang sosial dan kemausiaan. Kebanyakan orang yang terlibat di dalamnya adalah mereka dengan jiwa sosial tinggi. Karenanya, kehadiran akan pemimpin yang etis sangat dibutuhkan. Dalam kondisi kepemimpinan etis yang tinggi, pemimpin benar-benar berperilaku sesuai norma etika dan agama. Hal ini ditunjukkan dengan sikap pemimpin yang jujur tanpa ada informasi yang disembunyikan dari anggota, melibatkan partisipasi anggota dalam pengambilan keputusan, serta mempertimbangkan kesejahteraan anggota dan anak asuh. Kepemimpinan yang etis diyakini dapat membuat anggota organisasi lebih percaya, merasa dihargai, dilindungi dan diakui keberadaaanya sehingga motivasi kerja anggota meningkat dan berikutnya kinerja organisasi juga akan baik (Seliamang, 2015). Hasil penelitian ini sejalan dengan Seliamang (2015) yang juga menemukan bahwa ethical leaderhisp berpengaruh positif dan signifikan terhadap kinerja organisasi.

Secara khusus, peneltian ini juga mengonfirmasi hubungan positif motivasi kerja pegawai dan kinerja organisasi. Motivasi kerja penting dimiliki oleh setiap individu sebagai dorongan untuk bekerja dengan giat dan dengan mudah menyesuaikan diri dengan lingkungan kerja secara positif, sehingga dapat mencapai tujuan organisasi sesuai harapan. Individu yang memiliki motivasi kerja yang tinggi memiliki rasa tanggungjawab yang tinggi, semangat bekerja yang tinggi, ikut berpartisipasi aktif dan mempunyai keinginan yang tinggi untuk bisa mencapai tujuan organisasi (Murti \& Srimulyani, 2013). Rasa tanggungjawab yang tinggi terhadap masa depan anak asuh ditunjukkan dengan terus meningkatkan fasilitas anak asuh dan mengasuh anak asuh sesuai dengan standar pelayanan minimal yang berlaku. Dengan motivasi kerja yang tinggi, aktivitas dalam organisasi berjalan efektif sehingga sasaran dan tujuan organisasi dapat tercapai dengan maksimal (Brahmasari \& Suprayetno, 2008). Hasil ini sesuai dengan penelitian yang dilakukan oleh Hara (2016) yang menemukan bahwa motivasi kerja mempunyai pengaruh positif terhadap kinerja organisasi. Motivasi yang tinggi meningkatkan upaya pekerja dalam memaksimalkan usahanya untuk mencapai tujuan organisasi.

\section{SIMPULAN DAN SARAN}

Penelitian ini bertujuan untuk menguji pengaruh akuntabilitas, budaya organsisasi dan ethical leadership terhadap motivasi kerja pegawai dan kinerja panti asuhan di 


\section{Nominal: Barometer Riset Akuntansi dan Manajemen}

P-ISSN: 2303-2065 E-ISSN: 2502-5430

Volume 9 No 1 (2020)

lingkup Daerah Istimewa Yogyakarta. Penelitian ini menemukan bahwa budaya organisasi dan ethical leadership berpengaruh positif terhadap motivasi kerja para pengurus panti asuhan dan kinerja organisasi panti asuhan. Sedangkan akuntabilitas hanya berpengaruh terhadap kinerja panti asuhan namun tidak berpengaruh terhadap motivasi kerja pengurus panti asuhan.

Dari temuan ini, implikasi penting yang perlu ditekankan adalah pentingnya akuntabilitas agar dijalankan oleh panti asuhan agar informasi yang terkandung di dalamnya dapat dipergunakan sebagai bahan pertimbangan dalam pengambilan keputusan, khususnya terkait upaya peningkatan kinerja. Berikutnya, perlu adanya upaya yang mengatur agar bagaimana budaya di panti asuhan dapat berjalan kondusif mengingat hal tersebut dapat meningkatkan motivasi kerja pegawai panti asuhan yang berikutnya berkontribusi terhadap pencapaian kienrja panti asuhan yang lebih baik. Terakhir, hal yang juga tidak kalah penting adalah ethical leadership di panti asuhan. Perlu diberlakukan fit and proper test ketika pemilihan manajemen puncak atau pengurus harian panti asuhan untuk menjamin bahwa calon pemipinnya memiliki pribadi yang etis. Hal ini penting dilakukan mengingat pemimpina etis sangat berperan dalam memotivasi para pegawai yang selanjutnya juga berkaitan dengan peningkatan kinerja organisasi panti asuhan.

Terlepas dari temuan dan implikasi yang cukup bernilai, penelitian ini tidak luput dari kekurangan. Pertama, penelitian ini hanya dilakukan pada lingkup Daerah istimewa Yogyakarta sehingga kemampuan hasil generalisirnya relative masih lemah. Karenanya, penelitian berikutnya perlu dilakukan di tempat lain untuk mendukung atau bahkan membantah hasil dari penelitian ini. Berikutnya, penelitian ini tidak menguji apakah motivasi kerja memiliki peran pemediasi atau pemodarator. Karenanya sangat menarik jika penelitian berikutnya mempertimbangkan hal tesebut. Terakhir, penelitian ini menggunakan pendekatan survey yang sarat dengan kelemahan dari aspek kedalaman hasil investigasi. Penelitian berikutnya sangat dianjurkan untuk menggunakan pendekatan lain seperti studi kasu, longitudinal, fenomenologias, atau metode riset campuran dengan pendekatan triangulasi agar mendapatkan validitas internal dan eksternal hasil penelitian yang lebih kuat.

\section{DAFTAR PUSTAKA}

Arifin, A. Z. (2014). "Pengaruh Budaya Organisasi dan Akuntabilitas Publik Terhadap Kinerja Organisasi Publik (Studi Pada Rumah Sakit Daerah Massenrempulu, Kabupaten Enrekang)". Skripsi, Universitas Muhammadiyah Yogyakarta. 
Auditya, L., dan L. Husaini. (2013). "Analisis pengaruh akuntabilitas dan transparansi pengelolaan keuangan daerah terhadap kinerja pemerintah daerah" Jurnal Fairness, 3 (1), 21-41

Baihaqi, M. I. (2013). "Pengaruh Kepemimpinan dan Disiplin Kerja terhadap Kinerja Pegawai dengan Kepuasan Kerja Sebagai Variabel Moderating (Studi Kasus pada Dinas Kehutanan Kabupaten kutai Timur, Kalimantan Timur)", Skripsi, Universitas Muhammadiyah Surakarta.

Brahmasari, I. A., dan A. Suprayetno. (2008). "Pengaruh motivasi kerja, kepemimpinan dan budaya organisasi terhadap kepuasan kerja karyawan serta dampaknya pada kinerja perusahaan (Studi kasus pada PT. Pei Hai International Wiratama Indonesia)" Jurnal Manajemen dan kewirausahaan, 10 (2), 124-135

Celani, A., dan P. Singh. (2011). "Signaling theory and applicant attraction outcomes" Personnel review, 40 (2), 222-238

Certo, S. T. (2003). "Influencing initial public offering investors with prestige: Signaling with board structures" Academy of Management Review, 28 (3), 432-446

Connelly, B. L., S. T. Certo, R. D. Ireland, dan C. R. Reutzel. (2011). "Signaling theory: A review and assessment" Journal of Management, 37 (1), 3967.

Ghozali, I. (2012). Aplikasi Analisis Multivariate dengan Program IBM SPSS 20. 6 ed. Semarang: Badan Penerbit Universitas Diponegoro.

Hara, M. (2016). "Pengaruh Budaya Organisasi, Komitmen Organisasi, Pengendalian Intern, Motivasi, Akuntabilitas, Dan Kepuasan Kerja
Terhadap Kinerja Organisasi Kota Surakarta", Skripsi, Universitas Muhammadiyah Surakarta.

Hartono, J. (2013). Guidance for Survey Study with Questionnaire. Yogyakarta: BPFE Yogyakarta.

Hughes, R. L. (2012). Leadership: Enhancing the lessons of experience: New York: ERIC.

Imelda ， R. H. N. (2005). "Implementasi balanced scorecard pada organisasi publik" Jurnal Akuntansi dan Keuangan, 6 (2), 106-122

Indayati, N. (2012). "Pengaruh Keterlibatan Karyawan, Budaya Organisasi, dan Gaya Kepemimpinan terhadap Komitmen Organisasional dalam Meningkatkan Kinerja Karyawan (Studi pada Universitas Brawijaya)" Jurnal Aplikasi Manajemen, 10 (2), 344-356

Johan. 2006. "Standardisasi Panti asuhan Sosial. [Internet] Dinsos Jogja".

http://jurnalsumatra.com/panti-asuhankeluhkan-pelayanannya-kurangmaksimal/ pada tanggal 22 Maret 2020 Pukul 19.00 WIB

Kurniawan, M. (2013). "Pengaruh Komitmen Organisasi, Budaya Organisasi, Dan Kepuasan Kerja Terhadap Kinerja Organisasi Publik (Studi Empiris pada SKPD Pemerintah Kabupaten Kerinci)" Jurnal Akuntansi, 1 (3), 1-15

Lina, D. (2014). "Analisis pengaruh kepemimpinan dan budaya Organisasi terhadap kinerja pegawai dengan sistem Reward sebagai variabel moderating" JRAB: Jurnal Riset Akuntansi \& Bisnis, 14 (1), 35 47

Mahsun, M., F. Sulistyowati, dan H. A. Purwanegara. (2013). "Akuntansi 
Sektor Publik Edisi Ketiga". Yogyakarta: BPFE. Yogyakarta.

Murti, H., dan V. A. Srimulyani. (2013). "Pengaruh Motivasi Terhadap Kinerja Pegawai Dengan Variabel Pemediasi Kepuasaan Kerja Pada PDAM Kota Madiun" JRMA| Jurnal Riset Manajemen dan Akuntansi, 1 (1), 10-17

Nazaruddin, I., dan A. T. Basuki. (2015). "Analisis statistik dengan SPSS". Yogyakarta: Danisa Media.

Nugroho, I. (2013). "Mengembangkan Etika Kepemimpinan: Fenomena pada Jabatan Publik: Makalah disajikan dalam Diskusi Bulanan Malang Corruption Watch.

Nurrizkiana, B., L. Handayani, dan E. Widiastuty. (2017). "Determinants of Transparency and Accountability of Regional Financial Management and Its Implications to Trust of PublicStakeholders" Journal of Accounting and Investment, 18 (1), 28-47

Panti-Basa. (2016). "Data Panti Asuhan di Daerah Istimewa Yogyakarta".

Putra, D. (2013). "Pengaruh akuntabilitas publik dan kejelasan sasaran anggaran terhadap kinerja manajerial Satuan kerja perangkat daerah (Studi Empiris pada Satuan Kerja Perangkat Daerah Kota Padang)" Jurnal Akuntansi, 1 (1), 56-67

Ridwan, M. (2019). "Faktor-Faktor Yang Mempengaruhi Kinerja Organisasi Sektor Publik (Studi Empiris Pada Dinas-Dinas Di Kota Jambi)" Jurnal Riset Akuntansi Terpadu, 12(2), 222241

Robbins, P. S. (1995). "Teori Organisasi, Struktur Desain dan Aplikasi, Edisi Tiga". Jakarta: Arcan.
Robbins, S. P., dan T. A. Judge. (2008) "Perilaku Organisasi Buku 1". Jakarta: Salemba Empat.

Rumintjap, M. L. (2013). "Penerapan balanced scorecard sebagai tolak ukur pengukuran kinerja di RSUD Noongan" Jurnal EMBA: Jurnal Riset Ekonomi, Manajemen, Bisnis dan Akuntansi, 1 (3), 71-82

Seliamang, Y. M. (2015). "Pengaruh Akuntabilitas, Budaya Organisasi Dan Ethical Leadership Terhadap Kinerja Panti Asuhan Di Provinsi Daerah Istimewa Yogyakarta" Simposium Nasional Akuntansi XVIII, 1-22

Shalahuddin, A., dan B. P. Marpaung. (2016). "Pengaruh Kompensasi Dan Budaya Organisasi Terhadap Kinerja Pegawai Dengan Motivasi Kerja Sebagai Variabel Perantara" Jurnal Manajemen Teori dan Terapan| Journal of Theory and Applied Management, 7 (1), 22-34

Sofyani, H., dan R. Akbar. (2013). "Hubungan Faktor Internal Institusi dan Implementasi Sistem Akuntabilitas Kinerja Instansi Pemerintah (SAKIP) di Pemerintah Daerah. Jurnal Akuntansi dan Keuangan Indonesia" Jurnal Akuntansi dan Keuangan Indonesia, 10 (2), 207-235.

Spence, M. (2002). "Signaling in retrospect and the informational structure of markets" American Economic Review, 92 (3), 434-459

Sugiyono, D. 2008. "Metode penelitian bisnis". Bandung: Pusat Bahasa Depdiknas.

Susanto, H., dan N. Aisiyah. (2010). "Analisis pengaruh kepemimpinan dan budaya kerja dengan motivasi sebagai variabel intervening terhadap kinerja karyawan di Kantor 
Nominal: Barometer Riset Akuntansi dan Manajemen

P-ISSN: 2303-2065 E-ISSN: 2502-5430

Volume 9 No 1 (2020)

Pertanahan Kabupaten Kebumen". MAGISTRA, 22 (74), 15-23

Trang, D. S. (2013). "Gaya kepemimpinan dan budaya organisasi pengaruhnya terhadap kinerja karyawan" Jurnal EMBA: Jurnal Riset Ekonomi, Manajemen, Bisnis dan Akuntansi, 1 (3), 33-41

Ulum, I., dan H. Sofyani. (2016). Akuntansi (Sektor) Publik. Yogyakarta: Aditya Media Publishing.

Wibowo, A. J. I. (2016). "Kepemimpinan Beretika dan Kinerja Organisasi: Studi Kasus Indomie di Taiwan dan Hong Kong" Jurnal Manajemen Maranatha, 16 (1), 44-56

Sugiyono, D. (2008). Metode penelitian bisnis. Bandung: Pusat Bahasa Depdiknas.

Trang, D. S. (2013). Gaya kepemimpinan dan budaya organisasi pengaruhnya terhadap kinerja karyawan. Jurnal EMBA: Jurnal Riset Ekonomi, Manajemen, Bisnis dan Akuntansi, 1 (3), 17-23 